\title{
Allelopathic potential of Parthenium hysterophorus on wheat, Triticum aestivum. rice, Oryza sativa, soybean, Glycine max and pigeonpea, Cajanus cajan \\ Goverdhan Singh Thakur and *Shriram Kunjam
}

\author{
Department of Botany, \\ Government V.Y.T. PG Autonomous College, \\ DURG (CHHATTISGARH)-491001 INDIA \\ *Corresponding Author \\ Email : shriramkunjam07@gmail.com
}

Received : 25.08.2020; Accepted : 22.09.2020

\begin{abstract}
Allelopathic effects of Parthenium hysterophorus were studied on seed germination and seedling growth of Triticum aestivum, Oryza sativa, Glycine max and Cajanus cajan. The shade dried leaves of Parthenium hysterophorus were soaked in distilled water for 24 hours at room temperature to obtain aqueous extract and sterilized seeds were treated with $2 \%, 4 \%$, $6 \%, 8 \%$ and $10 \%$ concentration of $P$. hysterophorus leaves aqueous extract. The germinated seeds were counted every day to observe mean germination time. It has been found that significant time is taken to germinate with increasing concentration. It has been also observed that germination percentage, root length, shoot length and seedling vigour value were reduced at $>2 \%$ as compared to control. The $10 \%$ aqueous extract showed the maximum inhibitory effect on seedling growth. In the present investigation, the leaves aqueous extract of $P$. hysterophorus had strong inhibiting effects on seed germination and seedling growth. It is necessary to keep this weed under check at the emerging stage at agro crop field so that crop growth constraint may be avoided.
\end{abstract}

KEY WORDS : Allelopathy, Aqueous extract, Mean germination time, Parthenium hysterophorus L., Seed germination, Seedling growth.

\section{Introduction}

The term allelopathy, from the Greek-derived compounds allelo- and -pathy (meaning "mutual harm" or "suffering"), was first coined and defined the term allelopathy in 1937 by Hans Molisch. Allelopathy is a phenomenon involving either direct or indirect and either beneficial or adverse effects of a plant (including microorganisms) on another plant through the release of chemicals in the environment ${ }^{16}$. Allelochemicals are the secondary metabolites produced by plants and are products of primary metabolic processes. Allelopathic substances released by the plants accumulate in the soil to physiologically active levels. Parthenium hysterophorus L. (Family - Asteraceae) is an alien annual herbaceous weed; allelopathic properties cause suppression of natural vegetation and severely affect the crop plants posing a strong threat crop production and bio-diversity. Aqueous extract ${ }^{10,15}$ of Parthenium hysterophorus shows the inhibitory effect on of plant growth different species. The plant releases the number of allelochemicals to surround such as phenolic acids, sesquiterpene, lactones especially Parthenin ${ }^{10,18}$. Plants release phytochemicals from dead tissues and their incorporation to the soil could be accelerated by leaching thus facilitating their harmful effects in the agro crop. Parthenium hysterophorus $\mathrm{L}$. produce allelochemicals that suppress the production of crops $^{9}$. Triticum aestivum $\mathrm{L}$, Oryza sativa L., Glycine max L. and Cajanus cajan L. are the most widely consumed agro crop in India. The weed infestation is recognized is a serious biological suppression to total crop production. Therefore the allelopathic potential of leaf aqueous extracts of abnoxious Parthenium hysterophorus L. on the germination and early growth of above mentioned agro crop plants were investigated in the laboratory.

\section{Materials and Methods}

\section{Sample Collection and Preparation of Plant Extracts}

Fresh $P$. hysterophorus plants were collected from the agriculture field of Durg district of Chhattisgarh and was brought to the laboratory. Thenafter washed thoroughly with water and it was kept to dry in shade for ten days. Leaf samples were separated, powdered and stored in plastic bottles at room temperature (average 
TABLE-1 : Effect of Leaf aqueous extract of Parthenium hysterophorus on germination \& seedling growth of Wheat

\begin{tabular}{l|c|c|c|c|c|c|c}
\hline Conc. \% & Germination \% & GI & MGT & $\begin{array}{c}\text { Root } \\
\text { Length } \\
\text { (cm) }\end{array}$ & $\begin{array}{c}\text { Shoot } \\
\text { Length } \\
\text { (cm) }\end{array}$ & SVI & Biomass \\
\hline Control & 100 & 6.72 & 1.9 & 19.15 & 12.05 & 1915 & 0.35 \\
\hline $2 \%$ & 63.33 & 4.08 & 1.88 & 11.45 & 8.51 & 528.23 & 0.21 \\
\hline $4 \%$ & 50 & 2.22 & 2.95 & 10.76 & 6.77 & 534.66 & 0.27 \\
\hline $6 \%$ & 36.67 & 2.52 & 2.27 & 8.93 & 4.44 & 306.4 & 0.2 \\
\hline $8 \%$ & 30 & 1.74 & 3.33 & 6.97 & 2.21 & 256.63 & 0.11 \\
\hline $10 \%$ & NG & NG & NG & NG & NG & NG & NG \\
\hline F Value & 21.18 & 17.64 & 11.34 & 198 & 169.2 & 33.11 & 66.16 \\
\hline LSD 0.05\% & 15.95 & 0.287 & 0.52 & 2.36 & 0.73 & 257.04 & 1.25 \\
\hline
\end{tabular}

GI= Germination Index, MGT = Germination Mean Time, SVI = Seedling Vigour Index .

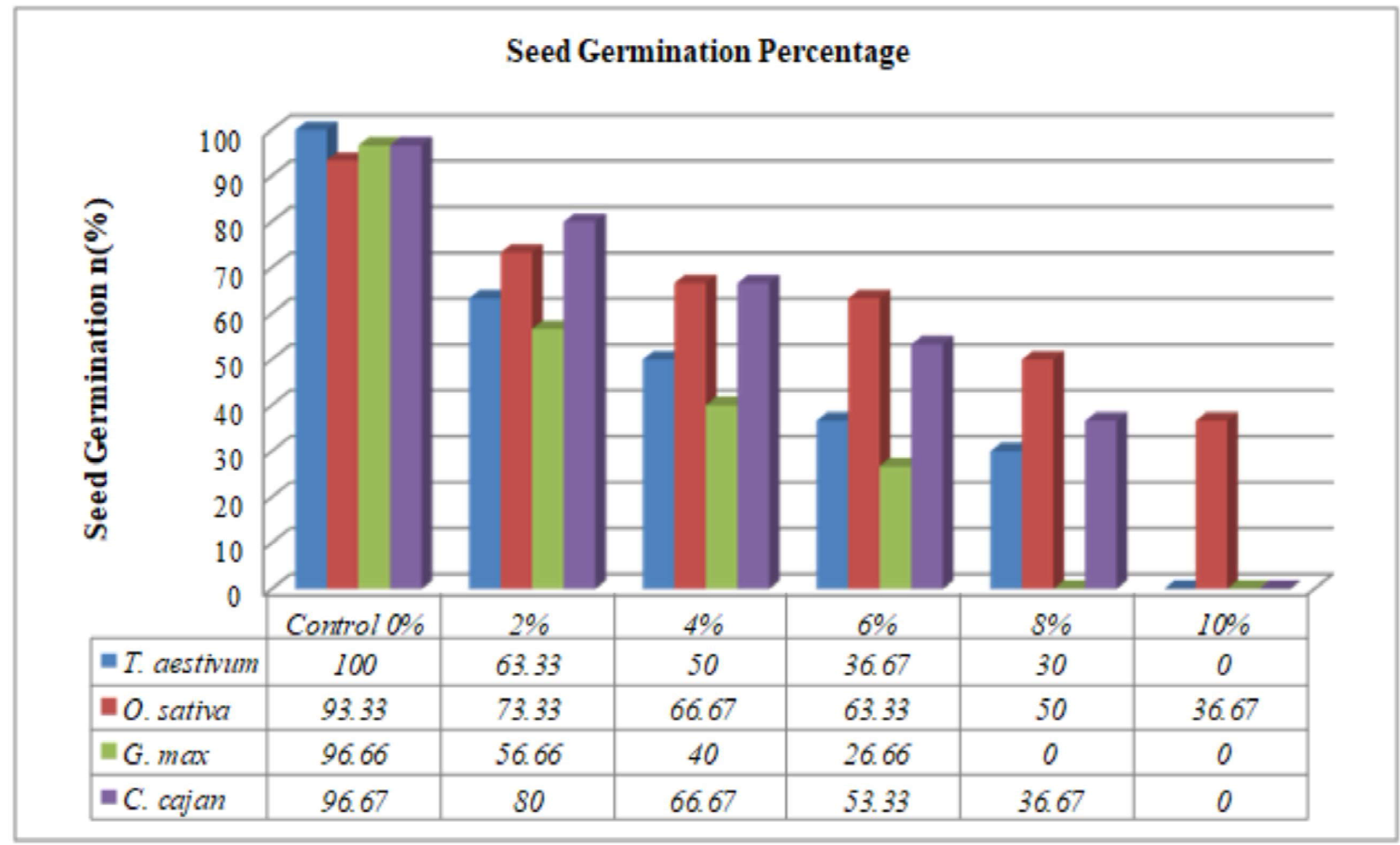

Fig. 1: Effect of leaf aqueous extract of Parthenium hysterophorus on seed germination percentage of test plant species 
Allelopathic potential of Parthenium hysterophorus on wheat, Triticum aestivum. rice, Oryza sativa, soybean, Glycine max and pigeonpea, Cajanus cajan 199

TABLE-2 : Effect of Leaf aqueous extract of Parthenium hysterophrus on germination \& seedling growth of Rice

\begin{tabular}{l|c|c|c|c|c|c|c}
\hline Conc. \% & Germination \% & GI & MGT & $\begin{array}{c}\text { Root } \\
\text { Length } \\
\text { (cm) }\end{array}$ & $\begin{array}{c}\text { Shoot } \\
\text { Length } \\
(\mathbf{c m})\end{array}$ & SVI & Biomass \\
\hline Control & 93.33 & 2.49 & 3.85 & 7.3 & 6.16 & 680 & 0.596 \\
\hline $2 \%$ & 73.33 & 1.91 & 4 & 7.53 & 5.19 & 553 & 0.396 \\
\hline $4 \%$ & 66.67 & 1.7 & 4.14 & 6.82 & 5.82 & 455 & 0.28 \\
\hline $6 \%$ & 63.33 & 1.52 & 4.28 & 6.28 & 4.71 & 399.16 & 0.173 \\
\hline $8 \%$ & 50 & 1.26 & 4.08 & 5.24 & 4.28 & 262.53 & 0.136 \\
\hline $10 \%$ & 36.67 & 0.89 & 4.22 & 4.7 & 4.13 & 175.1 & 0.083 \\
\hline F Value & 18.63 & 17.6 & 1.13 & 38.5 & 30.8 & 35.41 & 186.18 \\
\hline LSD 0.05\% & 9.83 & 0.29 & $\mathrm{NS}$ & 0.39 & 0.32 & 67.79 & 0.039 \\
\hline
\end{tabular}

GI= Germination Index,$M G T=$ Germination Mean Time, $S V I=$ Seedling vigour Index. NS =Not Significant

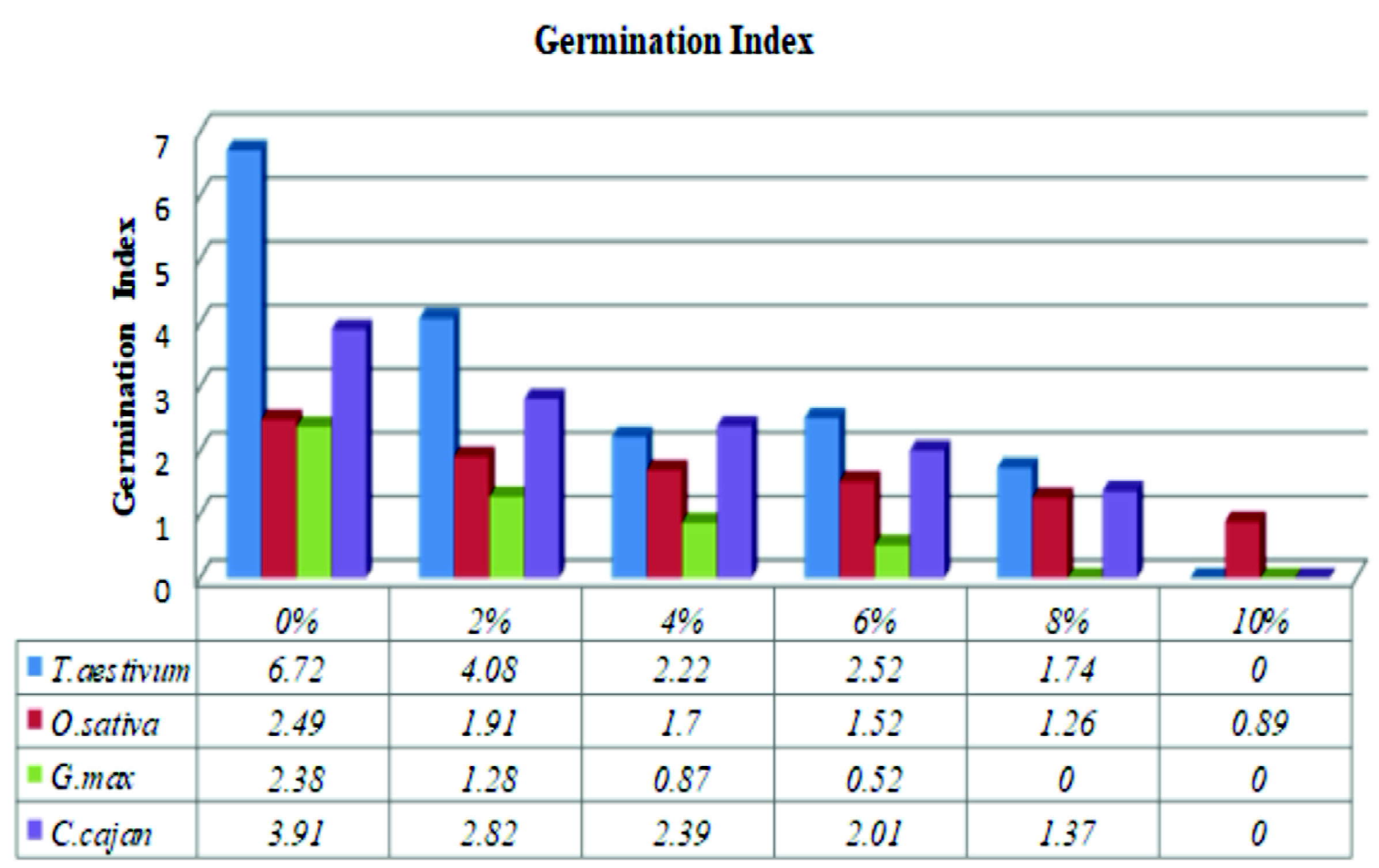

Fig. 2: Effect of leaf aqueous extract of Parthenium hysterophorus on germination index of test plant species 
TABLE-3 : Effect of Leaf aqueous extract of Parthenium hysterophorus on germination \& seedling growth of Soybean

\begin{tabular}{l|c|c|c|c|c|c|c}
\hline Conc. \% & Germination \% & GI & MGT & $\begin{array}{c}\text { Root } \\
\text { Length } \\
(\mathbf{c m})\end{array}$ & $\begin{array}{c}\text { Shoot } \\
\text { Length } \\
(\mathbf{c m})\end{array}$ & SVI & Biomass \\
\hline Control & 96.67 & 2.38 & 3.89 & 8.66 & 7.13 & 835.66 & 0.57 \\
\hline $2 \%$ & 56.67 & 1.28 & 4.6 & 2 & 0.63 & 113.33 & 0.41 \\
\hline $4 \%$ & 40 & 0.87 & 4.89 & 0.7 & 0.46 & 28.33 & 0.35 \\
\hline $6 \%$ & 26.67 & 0.52 & 5.21 & 0.43 & 0.36 & 12 & 0.2 \\
\hline $8 \%$ & NG & NG & NG & NG & NG & NG & NG \\
\hline $10 \%$ & NG & NG & NG & NG & NG & NG & NG \\
\hline F Value & 81 & 58.38 & 75.6 & 488 & 558 & 3040 & 243.3 \\
\hline LSD 0.05\% & 8.89 & 0.25 & 0.61 & 0.33 & 0.26 & 0.148 & 0.039 \\
\hline
\end{tabular}

GI= Germination Index, MGT = Germination Mean Time, SVI = Seedling Vigour Index .

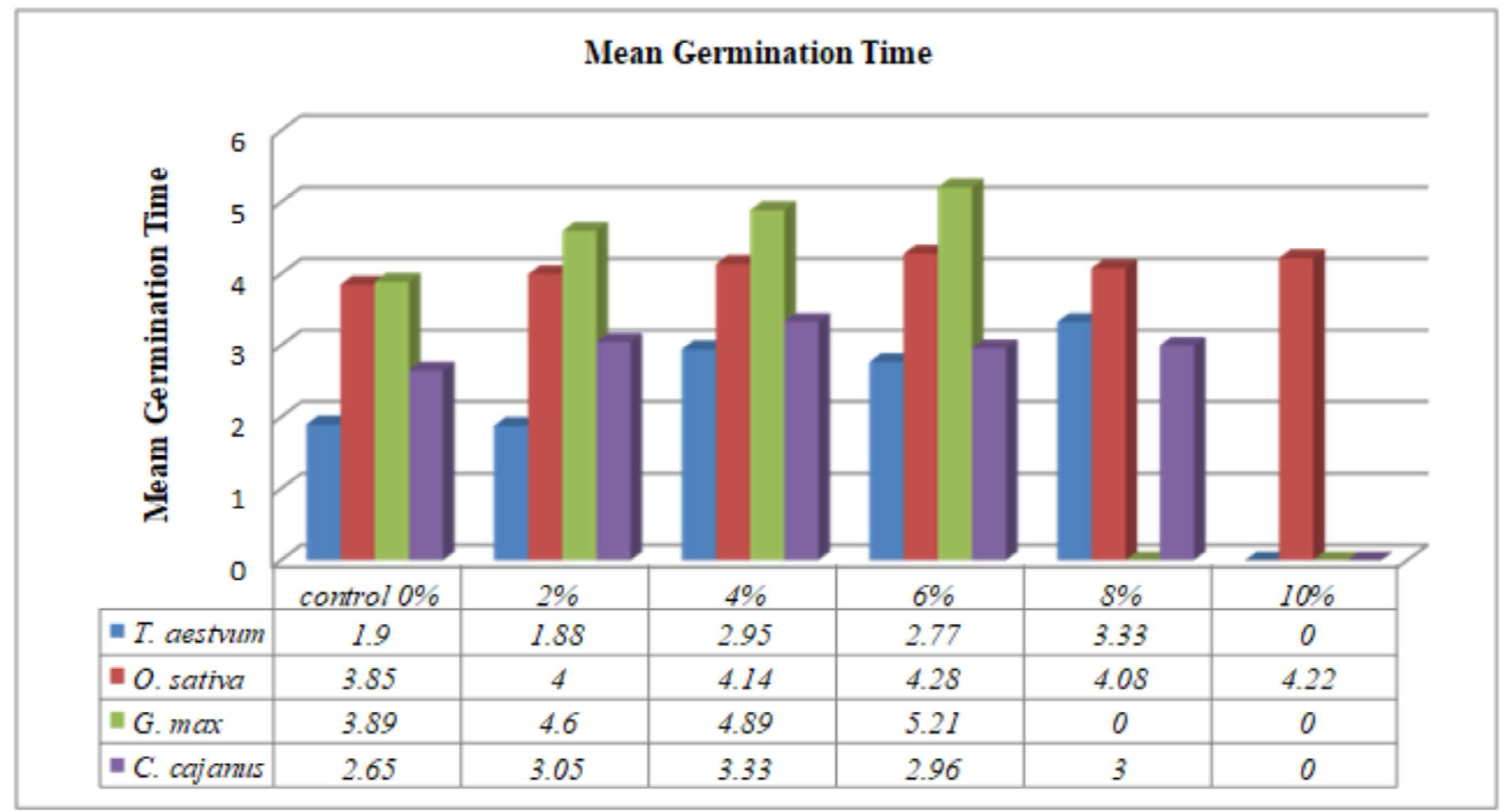

Fig. 3: Effect of leaf aqueous extract of Parthenium hysterophorus on mean germination time of test plant species 
Allelopathic potential of Parthenium hysterophorus on wheat, Triticum aestivum. rice, Oryza sativa, soybean, Glycine max and pigeonpea, Cajanus cajan 201

TABLE-4 : Effect of Leaf aqueous extract of Parthenium hysterophrus on germination \& seedling growth of pigeon pea

\begin{tabular}{l|c|c|c|c|c|c|c}
\hline Conc. \% & Germination \% & GI & MGT & $\begin{array}{c}\text { Root } \\
\text { Length } \\
\text { (cm) }\end{array}$ & $\begin{array}{c}\text { Shoot } \\
\text { Length } \\
\text { (cm) }\end{array}$ & SVI & Biomass \\
\hline Control & 96.67 & 3.91 & 2.65 & 4.28 & 3.1 & 412 & 0.8 \\
\hline $2 \%$ & 80 & 2.82 & 3.05 & 3.58 & 2.68 & 285 & 0.61 \\
\hline $4 \%$ & 66.67 & 2.39 & 3.33 & 3 & 2.47 & 198 & 0.52 \\
\hline $6 \%$ & 53.33 & 2.01 & 2.96 & 2.57 & 1.8 & 136.33 & 0.44 \\
\hline $8 \%$ & 36.67 & 1.34 & 3 & 1.67 & 1.29 & 60.33 & 0.32 \\
\hline $10 \%$ & NG & NG & NG & NG & NG & NG & NG \\
\hline F Value & 48.67 & 13.93 & 10.38 & 214.42 & 39.22 & 103 & 304.9 \\
\hline LSD 0.05\% & 10.69 & 0.77 & 0.84 & 0.22 & 0.39 & 32.33 & 0.04 \\
\hline
\end{tabular}

GI= Germination Index, MGT = Germination Mean Time, SVI = Seedling Vigour Index .

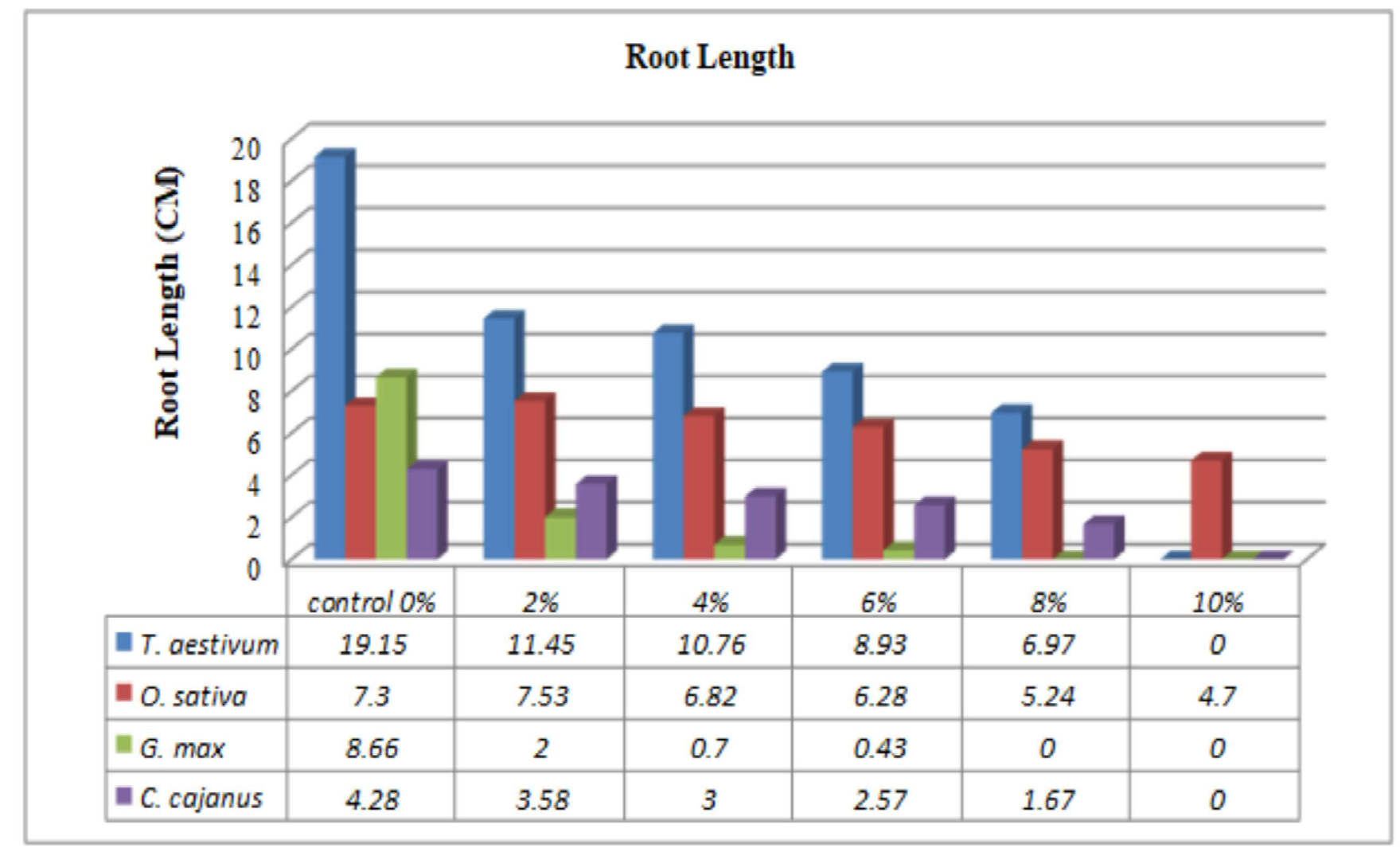

Fig. 4: Effect of leaf aqueous extract of Parthenium hysterophorus L. on root length of test plant species. 


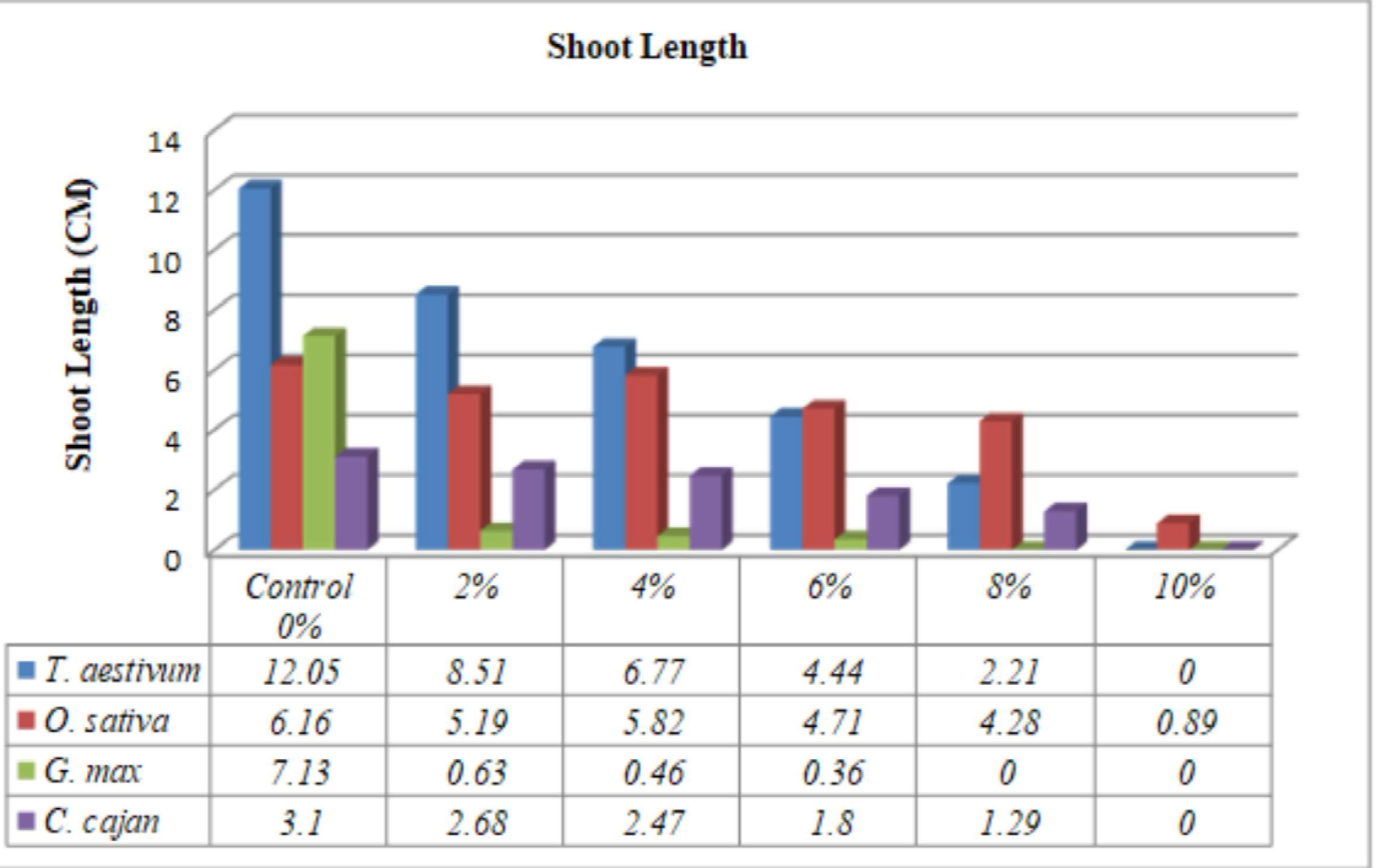

Fig. 5: Effect of leaf aqueous extract of Parthenium hysterophorus on shoot length of test plant species.

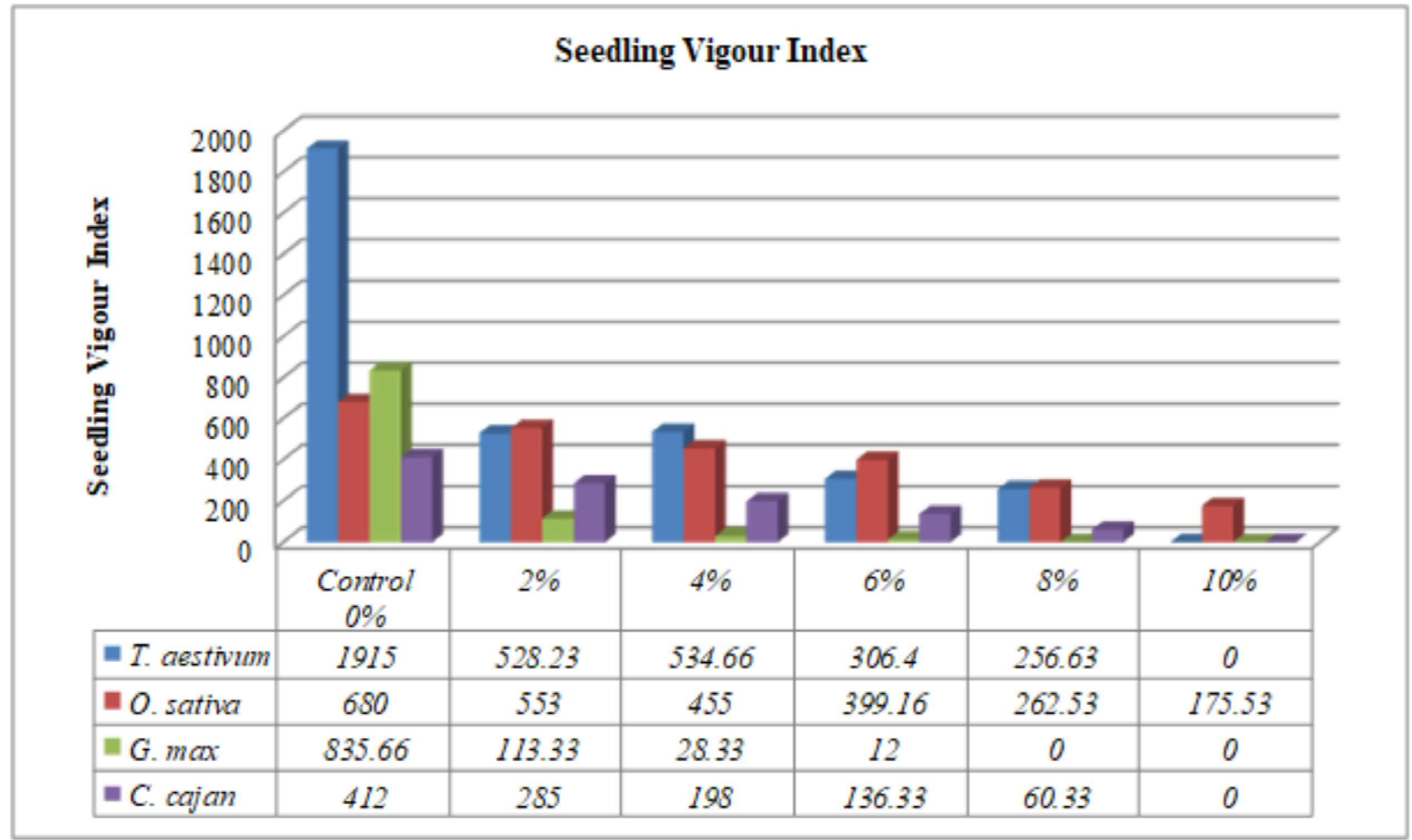

Fig. 6: Effect of leaf aqueous extract of Parthenium hysterophorus on seedling vigour index of test plant species 
$25^{\circ} \mathrm{C}$ ). Ten grams of powdered leaves were soaked in $100 \mathrm{ml}$ distilled water for $24 \mathrm{hr}$ at room temperature. The aqueous extract was filtrated through Whatman No. 1 filter paper and final volumes were adjusted to $100 \mathrm{ml}$; this gives $10 \%$ aqueous extract. The extracts were considered as stock solution and a series of the solution with different dilution strengths $(2,4,6,8, \& 10$.) were prepared. Each of ten healthy selected seeds was surface sterilized by $2 \%$ sodium hypochloride for $15 \mathrm{~min}$, then it was kept for germination in sterilized petridishes on 2folds of blotting paper and moister with $10 \mathrm{ml}$ of different concentration of aqueous extracts $(2 \%, 4 \%, 6 \%, 8 \%$, \& $10 \%)$. Each treatment was setup in 3 replicates with 10 seeds. A separate series of control was setup using distilled water. The petridishes were maintained under laboratory conditions at average $25^{\circ} \mathrm{C}$ temperature for ten days. Equal volumes of distilled water were added to petridishes for maintaining the moisture content of the blotting paper.

Germinated seeds were counted daily according to the seedling evaluation procedure ${ }^{2}$. The numbers of germinated seeds were recorded every 24 hours. Ten days sowing and germination, the percentage were calculated using the formula (Germinated seedlTotal seed $\times 100$ ) for each replication of the treatment.

Mean Germination Time: Mean germination times (MGT) were calculated according to the equation ${ }^{8}$.

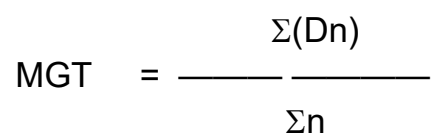

Where $\mathbf{n}$ is a number of seeds that emerged on day, and $\mathbf{D}$ is the number of days counted from the beginning of germination. The germination indexes (GI) were calculated by using the following formula2:

$$
\mathrm{GI}=\frac{\text { No. of germinated seeds }}{\text { Days of first count }}+\frac{\text { No. of germinated seeds }}{\text { Days of final count }}
$$

All the emerged seedlings from each replication were counted and the percentage of emergence were calculated by using the following formula:

$$
\text { Emergence \% }=\frac{\text { Emerged seed }}{\text { Total seed }} \times 100
$$

The length of roots and shoots were measured in centimeters from the point where the root and shoot join together at the end of the root and to the top of the shoot.

Seedling Vigour Index: Seedling Vigour Index (SVI) was calculated according to the following formula1.

$$
\mathrm{SVI}=\text { Germination/Emergence } \% \times \text { Radical length }(\mathrm{cm})
$$

\section{Biomass}

Roots and shoots of the entire seedling were separated, oven dried at $70^{\circ} \mathrm{C}$ for $48 \mathrm{hr}$ until they reached a constant weight and then they were weighed.

\section{Statistical Analysis}

The data were analyzed statistically using Fisher's analysis of variance using SPSS 16.0 software and treatment means were compared using the Least Significance Difference (LSD) at a probability level of $0.05 \%$.

\section{Results and Discussion}

Effect of aqueous leaves extract of Parthenium hysterophorus on seed germination and seedling growth behaviour of four agro crop plants Triticum aestivum, Oryza sativa, Glycine max and Cajanus cajan were studied and results are summarized (Tables 1 - 4 \& Figs. 1-7).

\section{Germination Percentage}

Germination percentages are summarized in Fig. 1. ANOVA showed a significant difference $(p<0.05)$ between treatments in all tested plant (Tables 1, 2, 3 and 4). The highest seed germination percentage was recorded in control (range from 93.33 to $100 \%$ ) and lowest seed germination in 8 and $10 \%$ (range from 30 to $36.67 \%$ ) extract of Parthenium hysterophorus. There was complete seed germination inhibition in Triticum aestivum, Glycine max and Cajanus cajan at $10 \%$ extract. It is highly interesting that there is a significant reduction in seed germination percentage with increasing concentration of $<2 \%$. This showed that leaf extract contains inhibiting chemicals resulting in the reduced germination of all agro crops. Plants exhibit allelopathy by releasing water soluble phytotoxin from leaves, stem, root, fruit and seeds, such metabolites play an inhibitory role in delay or completely inhibition of seed germination ${ }^{16}$. Seed germination was 


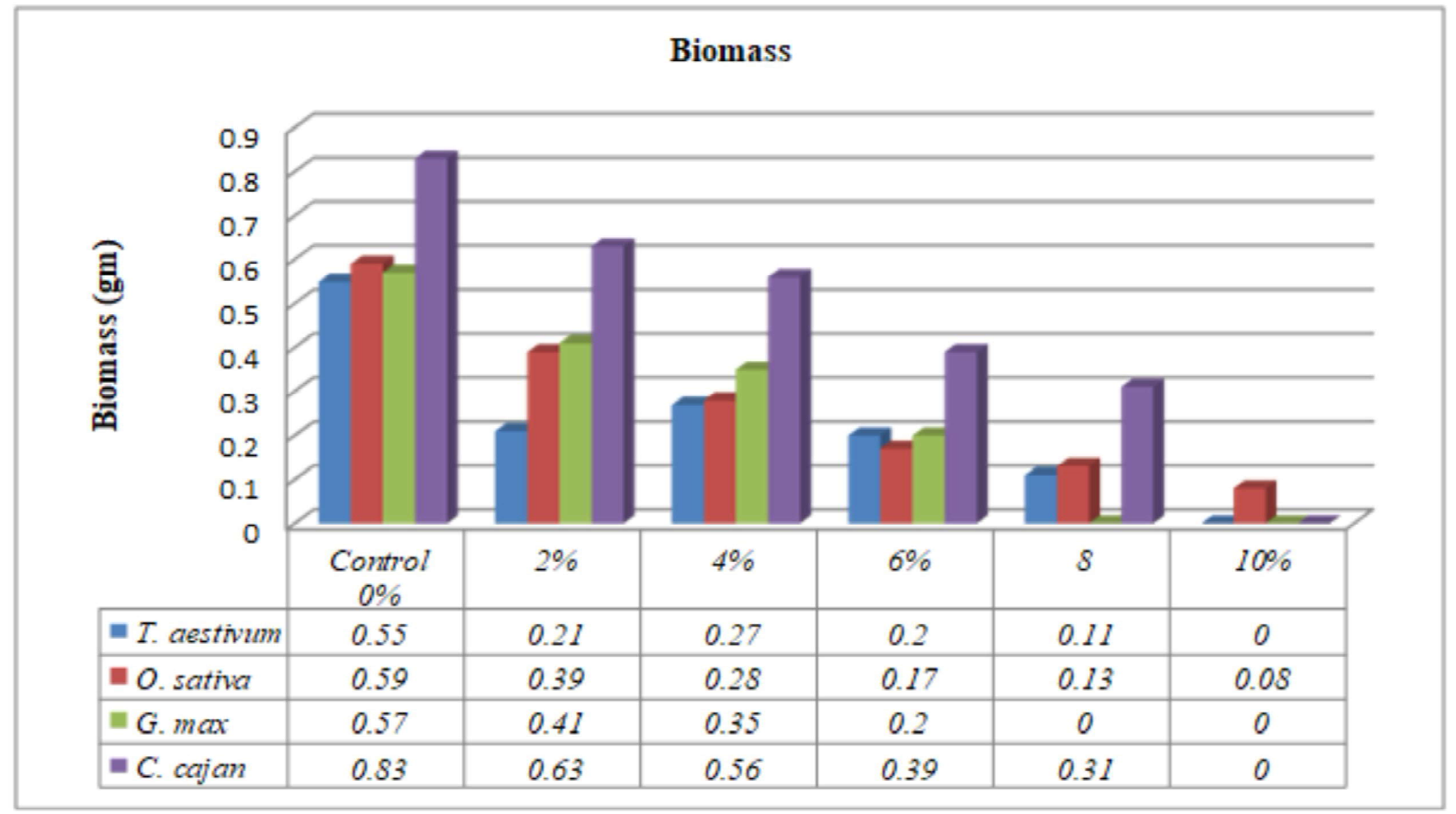

Fig. 7: Effect of leaf aqueous extract of Parthenium hysterophorus on biomass (g) of test plant species.

inhibited completely in Glycine max at $10 \%$ extract of Parthenium hysterophorus $\mathrm{L}$., this result is supported by earlier works $5,14,19$.

\section{Germination Index (GI)}

Germination index were recorded separately of each crop in Table-1 to 4 and $F$ value also recorded at $5 \%$ level of significance and data of all crops are summarized in Fig. 2. Germination index of all treatment crops showing significantly reduced with increasing concentration of extract. It is completely inhibited at 8 and $10 \%$ concentration extract in Glycine max L. This result is supported by previous findings ${ }^{5,6}$, whereas in Triticum aestivum L. and Cajanus cajan L. GI were completely inhibited at $10 \%$.

\section{Mean Germination Time (MGT)}

There were significant reductions of germination mean time at 2 to $10 \%$ concentration over control. Maximum MGT taken is recorded in Glycine max 5.21 at $6 \%$ and minimum in Triticum aestivum 1.9 at control. MGT is delayed in all experiment with increasing concentration. The maximum MGT indicates that there might be an inhibitory compound in aqueous of Parthenium hysterophorus which delayed the germination process of crop seeds. Results are supported by earlier finding ${ }^{3}$ which stated that Chickpea seeds soaked in the root extract of Asphodilus tenuifolus took more time for germination.

\section{Root and Shoot Length}

The root and shoot length of test crop plants were studied and results were recorded in Figures 4 \& 5 . Among all the plants, the concentration of extract increases the root and shoot length reduced as compared to control. The control showing maximum root length $19.15 \mathrm{~cm}$ in Triticum aestivum and minimum was recorded in Cajanus cajan. Triticum aestivum and Cajanus cajan were showing inhibitory action at $<2 \%$ and there was no result at $10 \%$ aqueous extract whereas in Glycine max completely inhibited at 8 and $10 \%$ aqueous extract in a same experimental condition. Triticum aestivum showed maximum shoot length followed by Glycine max, Oryza sativa and Cajanus cajan in control. The minimum root and shoot length were recorded in Glycine max having a range from 2 to $0.43 \mathrm{~cm}$ of root length and 0.63 to 0.36 $\mathrm{cm}$ of shoot length at the concentration of 2 to $6 \%$. Earlier works have also reported that foliar leachates of Parthenium hysterophorus reduces root and shoot elongation of Oryza sativa and Triticum aestivum ${ }^{17}$ Zea mays and Glycine max ${ }^{4}$. Parthenium hysterophorus in the form of extract or residue or growing weed effect the germination, growth and productivity of Zea mays ${ }^{13}$. This indicates the availability of the inhibitory chemicals in 
higher concentration in leaves ${ }^{11}$.

\section{Seedling Vigour Index (SVI)}

Seedling Vigour Index (SVI) is summarized in Fig. 6. ANOVA showed significant difference $(p<0.05)$ between treatments in all tested plants. Results showed that SVI reduces with increasing concentration of aqueous leaves extract of Parthenium hysterophorus as compared to control. The maximum SVI recorded in wheat (SVI-1950) followed by soybean (SVI- 835), rice (SVI- 680) and pigeon pea (SVI- 412) on control. The results are supported by the earlier finding ${ }^{13}$ which revealed that Parthenium hysterophorus in the form of extract affect the germination and growth of Zea mays.

\section{Biomass}

A dry weight of seedling (root \& shoot) completely inhibited in wheat and soybean, at $10 \%$ extract. The result showed that leaves extract had strong allelopathy property that reduced the biomass of test crop plants with increasing concentration (Fig. 7). Biomass of wheat, maize and soybean inhibit with increasing concentration of aqueous extract of Parthenium hysterophorus. ${ }^{5}$

\section{Conclusion}

The result of this study showed that Parthenium hysterophorus has allelopathic potential. It exhibited significant inhibitory effect on seed germination, seedling emergence, mean germination time, seedling vigour index and dry weight of root and shoot in all selected agro crops. Inhibitory effect increased with increasing concentration of the allelochemicals. Therefore it is necessary to keep this weed under check at the emergence stage at agro crop field so that its allelopathic based crop growth suppression may be avoided. Further studies on the interaction between allelochemicals and crop species are essential to interpret the mechanism of such allelopathic effects.

\section{References}

1. Abdul Baki AA, Anderson JD. Vigour Determination in Soybean Seed by Multiple Criteria. Crop Science. 1973; $13: 630-633$.

2. $\quad$ AOSA. Rules for testing seeds. J Seed Tecnol. 1990; 12: 1-112.

3. Baber BH, Tanveer A, Aziz A. Phytotoxic influences of Asphodelus temuifolius cav wiled onion on germination and seedling growth of wheat. Allelopathic Journal. 2009; 24 (2)341-350.

4. Bhatt BP, Chauhan DS, Todaria NP. Effect of weed leachates on germination and radical extension of some food crops. Indian Journal of Plant Physiology. 1994; 37: 177-179.

5. Dhole JA, Bodke SS, Dhole NA. Allelopathic effect of aqueous leaf extract of Parthenium hysterophorus L. on seed germination and seedling emergence of some cultivated crops. Journal of research in Biology. 2011; 1:15-18.

6. Dongre PN, Yadav B. Inhibitory allelopathic effect of weed leaf leachates on seed germination of pea (Pisum sativum L.). Crop Res Hisar. 2005; 29: 458-461.

7. Duke SO, Dayan FE, Rimando AM. Natural Products as tools for weed management. Proc. Japan Weed Sci. Suppl. 1998; 1-11.

8. Ellis RA, Roberts EH. The quantification of ageing and survival in orthodox seeds. Seed Sci Tecnol. 1981; 9 : 373-409.

9. Evans NC. Parthenium hysterophorus a review of its weed status and the possibilities for biological control. Biocontrol News and Information. 1997; 18: 89-98.

10. Kanchan SD. Growth inhibitors from Parthenium hysterophorus L., Current Science. 1975; 44: 358-359.

11. Kanchan SD, Jayachandra. Allelopathic effects of Parthenium hysterophorus L. IV. Identification of inhibitors. Plant and Soil. 1980; 55: 67-75.

12. Molisch H. Der Einfluss einer pflanze auf die andere. Allelopathic Fischer. Jena.1937.

13. Nganthoi Devi Y, Datta BK, Romesh Sagolshemcha, Irabanta Singh N. Allelopathic effect of parthenium hysterophorus $\mathrm{L}$. on growth and productivity of Zea mays $\mathrm{L}$. and its phytochemical screaning. International journal of current microbiology and applied sciences. 2014; 3(7) 837-846.

14. Oudhia P. Germination and seedling vigour of wheat as affected by Allelopathy of some obnoxious weeds. Indian Agric Sci Dig. 2001; 21: 275-276.

15. Rajan L. Growth inhibitors from Parthenium hysterophorus L. Current Science. 1973; 42(20) : 729 -730.

16. Rice EL. Allelopathy, 2nd Ed. Academic Press New York. 1984; 1-22

17. Singh SP, Sangeeta. Allelopathic potential of Parthenium hysterophorus L. Journal of Agronomy and Crop Science. 1991; 167: 201-206.

18. Swaminathan C, Vinaya RRS, Sureshi KK. Allelopathic Effects of Parthenium hyterophorus L. on germination and seedling growth of a few multipurpose tress and arable crops. Int. Tree Crops J. 1990; 6 : 143- 150.

19. Veenapani D. Inhibition in seed germination of Oryza sativa (paddy) by two weeds Species. Flora and Founa. 